OPEN ACCESS

Edited by:

Glen Reid,

University of Otago, New Zealand

Reviewed by:

Emanuela Felley-Bosco,

University of Zurich, Switzerland

Michael Grusch,

Medical University of Vienna, Austria

${ }^{*}$ Correspondence:

Massimiliano Mazza

massimiliano.mazza@irst.emr.it

Specialty section

This article was submitted to

Thoracic Oncology,

a section of the journal

Frontiers in Oncology

Received: 13 September 2019 Accepted: 17 December 2019

Published: 24 January 2020

Citation:

Nicolini F, Bocchini M, Bronte G, Delmonte A, Guidoboni M, Crinò L and Mazza M (2020) Malignant Pleural

Mesothelioma: State-of-the-Art on

Current Therapies and Promises for

the Future. Front. Oncol. 9:1519.

doi: 10.3389/fonc.2019.01519

\section{Malignant Pleural Mesothelioma: State-of-the-Art on Current Therapies and Promises for the Future}

\author{
Fabio Nicolini ${ }^{1}$, Martine Bocchini ${ }^{1}$, Giuseppe Bronte ${ }^{2}$, Angelo Delmonte ${ }^{2}$, \\ Massimo Guidoboni ${ }^{3}$, Lucio Crino ${ }^{2}$ and Massimiliano Mazza ${ }^{1 *}$
}

${ }^{1}$ Biosciences Laboratory, Istituto Scientifico Romagnolo per lo Studio e la Cura dei Tumori (IRST) IRCCS, Meldola, Italy, ${ }^{2}$ Department of Medical Oncology, Istituto Scientifico Romagnolo per lo Studio e la Cura dei Tumori (IRST) IRCCS, Meldola, Italy, ${ }^{3}$ Immunotherapy and Cell Therapy Unit, Istituto Scientifico Romagnolo per lo Studio e la Cura dei Tumori (IRST) IRCCS, Meldola, Italy

Malignant pleural mesothelioma (MPM) is a rare, aggressive cancer of the pleural surface associated with asbestos exposure. The median survival of MPM patients is a mere 8-14 months, and there are few biomarkers and no cure available. It is hoped that, eventually, the incidence of MPM will drop and remain low and constant, given that most nations have banned the use of asbestos, but in the meantime, the incidence in Europe is still growing. The exact molecular mechanisms that explain the carcinogenicity of asbestos are not known. Standard therapeutic strategies for MPM include surgery, often coupled with chemotherapy and/or radiotherapy, in a small percentage of eligible patients and chemotherapy in tumors considered unresectable with or without adjuvant radiotherapy. In recent years, several new therapeutic avenues are being explored. These include angiogenesis inhibitors, synthetic lethal treatment, miRNA replacement, oncoviral therapies, and the fast-growing field of immunotherapy alone or in combination with chemotherapy. Of particular promise are the multiple options offered by immunotherapy: immune checkpoint inhibitors, tumor vaccines, and therapies taking advantage of tumor-specific antigens, such as specific therapeutic antibodies or advanced cell-based therapies exemplified by the CAR-T cells. This review comprehensively presents both old and new therapeutic options in MPM, focusing on the results of the numerous recent and on-going clinical trials in the field, including the latest data presented at international meetings (AACR, ASCO, and ESMO) this year, and concludes that more work has to be done in the framework of tailored therapies to identify reliable targets and novel biomarkers to impact MPM management.

Keywords: malignant pleural mesothelioma (MPM), immunotherapy, mesothelin, CAR (chimeric antigen receptor) $\mathrm{T}$ cells, miRNA replacement

\section{INTRODUCTION}

Malignant pleural mesothelioma (MPM) is a rare, incurable, aggressive cancer of the pleural surface associated with asbestos exposure with a median survival of 8-14 months $(1,2)$. Although the incidence in some countries, e.g., the USA (3,200 cases/year) (3), is fairly constant, in Europe, it is growing and is expected to peak between 2020 and 2025 (1). Moreover, the migratory 
phenomena toward western countries from nations lacking legislation on asbestos use will render MPM even more frequent. At present, no actionable driver mutations have been identified in MPM. However, MPM carcinogenesis and outcome are influenced by many factors: BRCA-associated protein 1 (BAP1) expression status, CDKN2A and neurofibromatosis type 2 (NF2) tumor suppressor inactivation, overexpression of growth factors such as vascular endothelial growth factor (VEGF), mesothelin (MSLN) promoter methylation, and Ras/mitogen-activated protein kinase and phosphatidylinositol 3-kinase/mTOR pathway activation $(4,5)$.

\section{MESOTHELIOMA THERAPIES}

\section{Standard}

The standard therapeutic strategies for MPM are (i) surgery for resectable tumors, often combined with radiotherapy (RT) and/or chemotherapy (CT) (trimodality treatment), and (ii) CT or RT in unresectable tumor cases. To date, the only FDA- and EMA-approved frontline therapy is the cisplatin-pemetrexed combination (6-10). Only selected patients can benefit from a complete resection, either lungsacrificing surgery (extrapleural pneumonectomy, EPP) or lung-sparing (pleurectomy/decortication, P/D) (11-13). Surgery can be coupled with intraoperative treatments (14-17), but a general consensus on the proper multimodality approach is lacking.

\section{Radiotherapy}

RT is used as an adjuvant or neoadjuvant treatment in MPM, mainly in a palliative setting (8-10). As standard practice, patients undergoing an EPP receive adjuvant conventionally fractionated RT (50-60 Gy) in the ipsilateral hemithorax area (18, 19). In node-negative MPM patients, neoadjuvant therapy, based on intensity-modulated RT (IMRT) consisting of a fractionated irradiation of 5-6Gy, is delivered before EPP (20-22). In contrast, prophylactic radiotherapy of chest wall tracts after surgery to prevent parietal tumor seeding is not recommended anymore by the ASCO guidelines following the results of the SMART and PIT trials (23-25). Recently, adjuvant hemithoracic pleural RT has been shown to be effective and safe (26-28). Advanced RT treatments, e.g., proton therapy (29) or Arc therapy (a novel and accurate IMRT modality) (30), alone or combined with immunotherapies, are being tested to improve RT impact in MPM management.

\section{Angiogenesis Inhibitors}

The angiogenic process plays an important role in MPM maintenance. VEGF receptor tyrosine kinase inhibitor (TKI) monotherapy yielded modest results (31-37). The addition of bevacizumab, a humanized monoclonal antibody against VEGF, to cisplatin-pemetrexed CT increases the median overall survival (OS) from 16.1 to 18.8 months and progression-free survival (PFS) from 7.3 to 9.2 months, as shown in the phase III MAPS study (NCT00651456) (38). Since this therapeutic regimen showed manageable toxicities, it has been included in the
National Comprehensive Cancer Network guidelines (category 2A) (39), although it is not yet approved by the FDA or EMA. The SWOG S0905 phase I study evaluated the combination of cisplatin-pemetrexed CT with cediranib, a VEGF/PDGF receptor inhibitor, demonstrating a preliminary promising efficacy and reasonable toxicity profile (40) but, when compared to placebo, this combination failed to significantly increase OS and PFS in the following randomized phase II trial (41). Nintedanib is an inhibitor of three (triplet regimen) different growth factor receptors (VEGFR, PDFGR, and FGFR) and its administration in combination with $\mathrm{CT}$ improved the objective response rate (ORR) from 44 to $57 \%$ and the median PFS (9.7 vs. 5.7 months) compared to placebo in the LUME-Meso trial (42). Data from the phase III LUME-Meso trial (NCT01907100) have recently been published, and the primary PFS endpoint failed, not confirming the previous phase II trial results (43). Other TKIs, such as the anti-VEGFR axitinib (44) or the multi-target inhibitor of VEGFR1/2/3, FGFR-1, PDGFR- $\beta$, and RAF/cKit pathway sorafenib failed to improve median OS and PFS in chemonaive or CT-pretreated MPM patients $(45,46)$. The limited success of anti-angiogenic drugs is due to the lack of good predictive biomarkers to guide the selection of suitable patients for this therapy. Recently, blocking of FGF signaling has been pursued through the sequestration of FGFs with the GSK3052230 ligand trap molecule to avoid toxicities associated with FGFR inhibitors. A phase Ib study indicates that a combination of GSK3052230 plus cisplatin-pemetrexed-CT leads to an ORR of $44 \%$ and to a median PFS of 7.4 months with limited adverse events (47).

\section{Synthetic Lethal Therapies}

Some MPM tumors cannot synthesize arginine due to the loss of argininosuccinate synthetase 1 (ASS1) gene expression. ASS1 deficiency is twice more frequent in the biphasic/sarcomatoid histotypes than in the epithelioid subtype. In vitro experiments suggest that depletion of arginine through exposure to a specific deaminase leads to synthetic lethality (48). The TRAP phase I trial (NCT02029690) demonstrated a positive effect of treatment with pegylated arginine deaminase (ADI-PEG 20) combined with CT in ASS1-deficient MPM patients (49). The ATOMICMeso phase III trial (NCT02709512) is recruiting patients with ASS1 gene loss. Genomic studies on MPM cells reported a reduced or absent expression of an enzyme involved in DNA repair and $\mathrm{Ca}^{2+}$-dependent apoptosis BAP1 in $\sim 50 \%$ of sporadic MPMs. In vitro studies demonstrated that BAP1-mutated cells are less sensitive to ionizing radiation causing DNA doublestrand breaks $(50,51)$ or to the DNA synthesis inhibitor gemcitabine (52), highlighting the contribution of BAP1 in DNA damage signaling and repair and a possible role as a predictive biomarker (53). Inherited loss-of-function mutations in BAP1 predispose to multiple carcinomas, including mesothelioma (5456). Interestingly, MPM patients with germline mutated BAP1 or with genetic alterations in other DNA repair genes and treated with platinum CT showed a significantly longer median OS than patients devoid of the same mutations (57). Hence the BAP1 mutational status at diagnosis could be an important factor in 
predicting MPM patients' response to CT and may sensitize patients to synthetic lethality therapies that hit other components of the DNA repair machinery. Accordingly, as already suggested by Srinivasan et al. (58), the homologous repair (HR) component PARP-1 would be an excellent target for a synthetic lethality approach, given that MPM cells are frequently characterized by HR deficiency and unrepaired DNA damage accumulation due to the aforementioned BAP1 mutations. PARP-1 inhibitors, such as niraparib and olaparib, clearly decreased MPM cell survival, albeit regardless of BAP1 status. BAP1 loss also up-regulates the expression of EZH2, a Polycomb Repressive Complex2 (PRC2) component involved in epigenetic silencing (59) and oncogenic pathways (60), suggesting sensitivity of BAP1deficient MPM tumors to EZH2 inhibition. A phase II clinical trial (NCT02860286) is ongoing to evaluate the efficacy of the EZH2 inhibitor tazemetostat in MPM patients (61).

Finally, the synthetic lethality of inhibition of the Focal Adhesion Kinase (FAK) tyrosine kinase with loss of Merlin protein, the first involved in the survival, proliferation, and migration of tumor cells (62) and the second, a tumor suppressor encoded by the NF2 gene frequently mutated in MPM (5), has been proposed. Despite an encouraging positive trend observed in phase I trial in which FAK inhibitor GSK2256098 was tested in MERLIN-negative patients (63), a second large phase II trial (COMMAND, NCT01870609) demonstrated that neither PFS nor OS was improved by the FAK TKI defactinib as compared to placebo when administered as a maintenance treatment after frontline CT (64).

\section{Immunotherapies}

Multiple lines of evidence point to the involvement of the immune system in the pathogenesis and sensitivity to therapy of MPM $(65,66)$. Spontaneous regressions in some patients are attributable to an activation of the immune system (67, 68). Moreover, B cells are essential for a good prognosis (69) in murine preclinical models of mesothelioma treated with immunotherapy, indicating that antibodies are generated and contribute to the therapeutic effect. Also, the presence of cytotoxic $\mathrm{CD} 8^{+}$tumor-infiltrating lymphocytes (TILs) is a good prognostic marker in MPM $(70,71)$.

MPM can be immunogenic but develops mechanisms to evade immune eradication. PD-L1 is the ligand for PD-1, a receptor expressed by activated $\mathrm{T}$ and $\mathrm{B}$ cells. Binding of PD-L1 to PD1 affects effector T-cell and B-cell function and ultimately leads to exhaustion and apoptosis (72). Recently PD-L1 was shown to be expressed in $40 \%$ of MPMs, almost all of the sarcomatoid subtype, and was associated with a significantly poorer outcome, with a median survival of 5 months for PD-L1 ${ }^{+}$MPM patients vs. 14.5 months for PD-L1 ${ }^{-}$tumors ( $\left.p<0.0001\right)$ (73). However, PDL1 expression is heterogeneous among MPM cells and could vary during treatment, limiting the efficacy of anti-PD-(L)1 therapy $(74,75)$.

\section{Immune Checkpoint Inhibitors}

Immune checkpoint inhibitors (ICIs) are immune-modulating agents that boost the latent immune-response kept in check by the tumor. PD-1/PD-L1 and CTLA-4 inhibitory functions are targeted by immunomodulatory therapies, allowing T- and B-cell (re-)activation (76). Recently, many ICIs, including anti-CTLA4 , a glycoprotein expressed on regulatory and on activated $\mathrm{CD} 4^{+}$ and $\mathrm{CD}^{+} \mathrm{T}$ cells, or anti-programmed death 1 (PD-1)/PD-L1 antibodies, have been approved for the treatment of solid and hematological malignancies (76-78).

Despite early enthusiasm for the results of tremelimumab, an anti-CTLA-4 ICI, as first-line therapy (79), its use as a second- or third-line treatment demonstrated no benefit of CTLA-4 inhibition over placebo (DETERMINE, NCT01843374) (80). Nivolumab efficacy was tested as a second- or thirdline treatment alone vs. placebo in MPM patients in two recently completed phase II studies (NivoMes, NCT02497508, and MERIT, JapicCTI-163247) with ORRs of 24.0 and $29.4 \%$ and disease control rates (DCRs) of 50.0 and $67.6 \%$, respectively (81, 82). A clear correlation between response and PD-L1 expression was reported (81). An ongoing randomized, placebo-controlled phase III trial is testing the efficacy of nivolumab in relapsed mesothelioma (CONFIRM, NCT03063450) (83).

The anti-PD-1 ICI pembrolizumab has been evaluated in different phase I (KEYNOTE-028, NCT02054806) and II (NCT02399371) studies as a second- or third-line treatment, showing promising DCR and prolonged disease stability (84-86). The results from the randomized phase III trial PROMISE-meso (NCT02991482) were instead disappointing, with relapsed MPM patients receiving pembrolizumab or single-agent CT failing to show an improved median OS and PFS despite a superior ORR for pembrolizumab compared to a CT regimen (22 vs. 6\%) (87). Popat and colleagues suggest that ICI treatment should be tested at earlier stages and on patients that are better stratified to benefit from longer periods of immunotherapy.

Other ICIs, like the Inducible T-cell COStimulator (ICOS) agonist GSK3359609, alone or in combination with pembrolizumab, are being evaluated in advanced solid tumors including MPM (INDUCE-I, NCT02723955) (88).

\section{Combination Strategy}

Two ICIs against different targets can be combined. An ipilimumab (anti-CTLA-4) and nivolumab (anti-PD-1) combination was tested in the phase-II MAPS2 trial (89) in relapsed MPM patients. The results indicated that the primary endpoint, DCR after 12 weeks, was reached by combined therapy (50\%) and not by nivolumab alone (44\%). An ORR of 25.9 vs. $18.5 \%$ and a modest increase of median response duration (7.4 vs. 7.9 months) were achieved in the combination and nivolumab groups, respectively. Severe treatment-related side effects were registered in $17 \%$ of patients. The same combination is being investigated in a randomized phase III trial (Checkmate 743, NCT02899299) in the front-line setting (90). Similarly, the combined therapy of tremelimumab plus durvalumab, an anti-PD-L1 antibody, tested in the phase II NIBIT-MESO-1 trial (NCT02588131), resulted in grade 3-4 treatment-related side effects in $17.5 \%$ of patients (91). A phase III study is evaluating the combination of pembrolizumab with pemetrexed and platinum-based CT vs. pembrolizumab or CT alone as first-line treatment for MPM patients (NCT02784171). 


\section{INNOVATIVE THERAPEUTIC APPROACHES FOR MALIGNANT MESOTHELIOMA}

\section{miRNA Replacement}

miRNA replacement is an innovative anti-cancer approach that restores miRNA expression by delivering miRNAs or miRNA mimics. Restored miRNAs can interfere with the expression of proteins endowed with oncogenic activity (92-94) thereby inhibiting proliferation or inducing apoptosis of tumor cells (95).

miR-16 is often downregulated in MPM, while its expression in in vitro and in murine xenografts results in decreased cell proliferation, decreased glucose uptake, and increased mortality (95). The feasibility of miR-16 exploitation by delivering its mimic encapsulated into an anti-EGFR-coated bacteriallyderived shell termed EnGeneIC Dream Vector (TargomiR) (96) was shown in the NCT02369198 trial, which reported efficacy and good tolerability in patients with relapsed MPM (97). TargomiR therapy was associated with a drop in glucose uptake in $60 \%$ of patients as measured by PET-CT, while $73 \%$ of patients achieved disease control.

\section{Tumor Treating Fields}

Recently, the FDA approved an innovative first-line treatment for MPM patients as a humanitarian use device, called NovoTTF-100L, that is based on the delivery of specific electric frequencies (Tumor Treating Fields, TTF) in combination with $\mathrm{CT}$, to interfere with cancer cell proliferation. In vitro and in vivo data (98) are consistent with recent STELLAR phase II registration trial (NCT02397928) results, where a median OS of 18.2 months and low systemic toxicity have been experienced by the patients treated with TTF plus CT (99).

\section{Oncoviral Therapies}

In the wake of successful phase I and II studies (100, 101), a phase III clinical trial (INFINITE, NCT03710876) is evaluating the efficacy of an Adenovirus-Delivered Interferon Alpha-2b (rAd-IFN) in combination with celecoxib and gemcitabine in MPM patients who failed previous regimens. A phase II study (NCT04013334) is testing the efficacy of Ad-SGEREIC/MTG201, an adenoviral vector for the expression of Reduced Expression in Immortalized Cell (REIC)/Dickkopf3 (Dkk-3) gene in combination with nivolumab. The Dkk-3 protein is a Wnt signaling pathway antagonist that induces cancer cell death and antitumor immune response. A previous phase I/II study showed that intrapleural virus administration was safe and well-tolerated and that Dkk-3 gene expression allowed durable disease control (102). Preclinical studies evaluated the replication-competent neuroattenuated Herpex Simplex Virus (HSV-1716) as oncolytic virotherapy for mesothelioma, showing cytotoxicity in combination with CT or RT in vitro and reduced tumor growth also at low doses in vivo in MPM murine models (103). The results of a phase I/IIa trial (NCT01721018) testing the intrapleural administration of HSV-1716 demonstrated virus replication, pleural Th1 cytokine response, and anti-tumor immunoglobulin production (104). The use of other viral vectors [reviewed in (105)], such as attenuated versions of vaccinia or measles virus genetically engineered to produce human thyroidal sodium iodine symporter (NIS), is being investigated in different phase I clinical trials (NCT02714374, NCT01503177).

\section{Dendritic Cell Vaccination}

Cancer vaccines aim at inducing tumor-specific effector $\mathrm{T}$ cells that reduce tumor mass and induce tumor-specific memory $\mathrm{T}$ cells to curtail tumor relapse (106). Autologous dendritic cell vaccination (DCV) has shown efficacy in MPM treatment. The PMR-MM-002 clinical trial (NCT01241682) demonstrated the safety and feasibility of tumor lysate-pulsed dendritic cells as therapeutic adjuvants in MPM patients (107). The DENIM phase II/III randomized clinical trial (NCT03610360) will treat MPM patients with dendritic cell immunotherapy plus best supportive care (BSC) and compare the results with BSC alone (108). Other vaccination-based therapies currently under investigation are autologous DC loaded with Wilms' Tumor Antigen (WT1) (109) combined with CT (MESODEC, NCT02649829) and autologous TILs plus IL-2 (110). Based on the results obtained by PMR-MM-002 and by ICIs, a phase Ib MESOVAX clinical trial (NCT03546426) is recruiting MPM patients to test the efficacy of a tandem combination of autologous DCV and pembrolizumab at our institute.

\section{Mesothelioma Targeting Antigens}

MSLN is a glycoprotein expressed more on the cell surface of several tumors, including MPM cells, than in normal tissues (111). A phase II clinical trial (NCT00738582) testing amatuximab, a chimeric anti-MSLN mAb, plus standard CT compared to CT alone showed a promising OS of 14.8 months (112) that was not confirmed in the ARTEMIS trial (NCT02357147). Anetumab ravtansine (AR), an anti-MSLN antibody conjugated with the cytotoxic anti-tubulin drug ravtansine, showed a 50\% ORR and $90 \%$ DCR in pretreated patients (113). A second phase II randomized clinical trial showed that AR did not improve survival compared to the anti-mitotic chemotherapeutic, vinorelbine, as a single agent (114). The combined regimen of pembrolizumab plus AR will be evaluated in a phase $1 / 2$ trial (NCT03126630) that is recruiting only MSLN-positive patients. A phase I study (NCT02798536) is currently active to assess a novel low-immunogenic anti-MSLN recombinant immunotoxin, RG778/LMB-100 (115), composed of a human singlechain variable fragment ( $\mathrm{scFv}$ )-targeting moiety directed against MSLN linked to Pseudomonas exotoxin A (PE). The phase I trial NCT01675765 evaluated the sequential administration of the cancer vaccine CRS-207, an attenuated form of Listeria monocytogenes expressing MSLN, with or without cyclophosphamide followed by consolidation $\mathrm{CT}$, to stimulate an innate and adaptive immunity against MSLN-expressing cells. The cyclophosphamide arm showed acceptable toxicity and a DCR of $89 \%$, a PR of $54 \%$, an SD of $29 \%$, and a median PFS and OS of 7.5 and 14.7 months, respectively (116). 
The success of advanced cell-based therapies, e.g., Chimeric Antigen Receptor-transduced T cells (CAR-T) in hematological tumors, awoke interest as well for MPM (117). CAR-T-cell receptors directed against MSLN are being investigated in several phase I clinical trials. The critical issues in Adoptive Cell Therapy (ACT) and CAR-T treatment are the safety profile and the degree of off-tumor toxicity. Intravenous or intra-tumor administration of MSLN-CAR-T cells (NCT01355965) (118) obtained by Tcell electroporation with encoding mRNA to achieve transient expression resulted in moderate responses and low toxicity (119). A phase I study (NCT02414269) drawing on preclinical results in orthotopic mouse MPM models $(120,121)$ is ongoing to test the MSLN-CAR-T cells in multi-treated MPM patients. Preliminary results presented at the AACR [Abstract CT036, (122)] and ASCO [Abstract 2511, (123)] meetings this year have shown an ORR and DCR of 36.8 and $57.8 \%$, respectively, in a cohort treated off protocol in combination with pembrolizumab.

Fibroblast activation protein (FAP) is another interesting target expressed by all MPM subtypes and by cancer-associated fibroblasts (CAFs) and exploited by FAP-targeted CAR-T cells in an ongoing phase I trial (NCT01722149) (124) Preliminary results presented at the ESMO congress this year showed

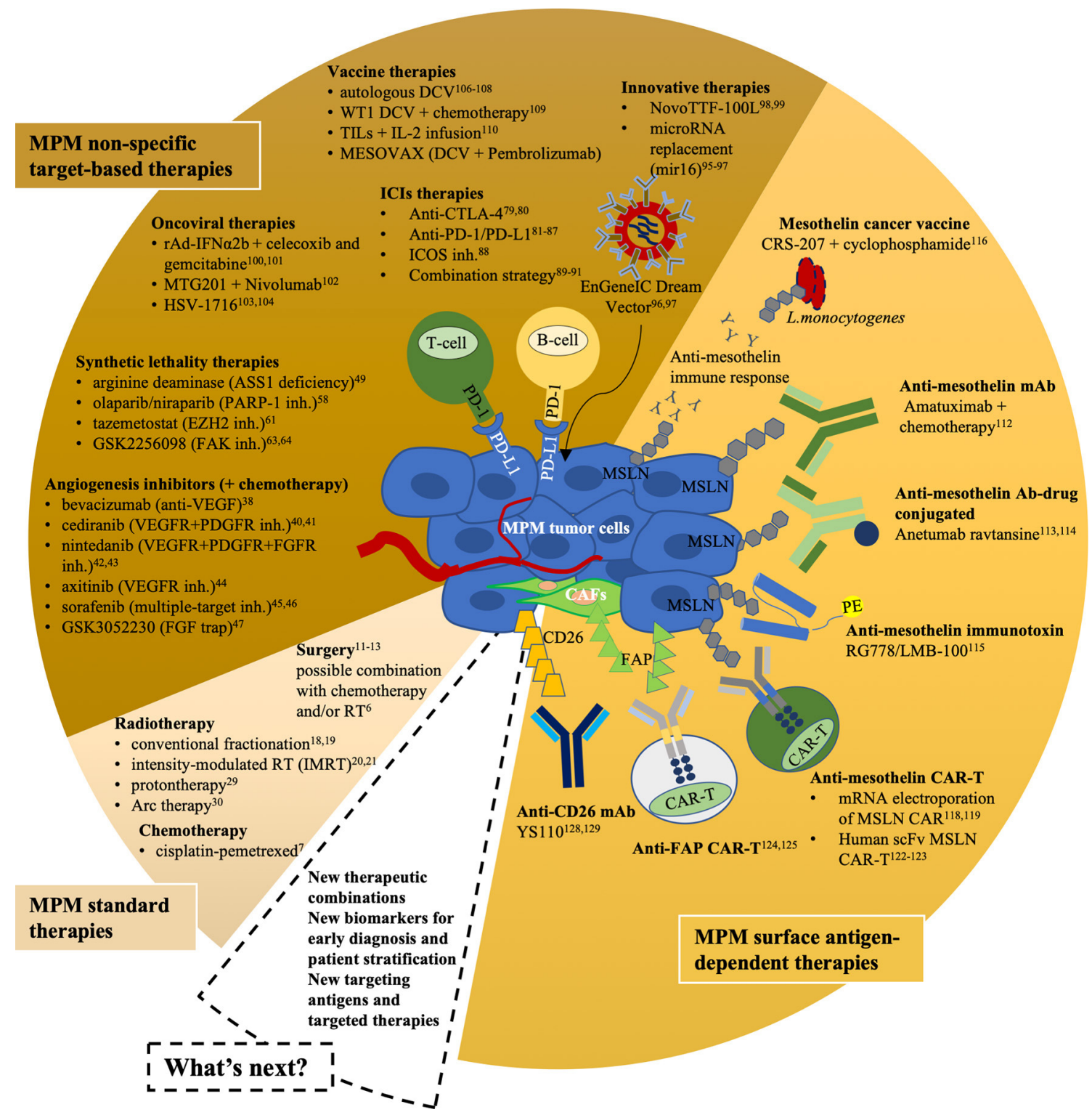

FIGURE 1 | Current and innovative clinical approaches for MPM. Different segments represent MPM standard therapies (light brown), MPM non-specific target-based therapies (brown), and MPM surface antigen-dependent therapies (orange). inh., inhibitor; DCV, dendritic cell vaccination; WT1, Wilms' Tumor Antigen; CAR, chimeric antigen receptor; IL-2, interleukin-2; TILs, tumor-infiltrating lymphocytes; MSLN, mesothelin; FAP, fibroblast activation protein; CAFs, cancer-associated fibroblasts; PE, Pseudomonas exotoxin A. 
TABLE 1 | Overview of MPM clinical trials.

\begin{tabular}{|c|c|c|c|c|c|c|c|c|c|}
\hline References & Clinical trial code & Acronymous & $\begin{array}{l}\text { Type of } \\
\text { study }\end{array}$ & Treatment & $\begin{array}{c}\text { OS } \\
\text { (months) }\end{array}$ & $\begin{array}{c}\text { PFS } \\
\text { (months) }\end{array}$ & ORR (\%) & DCR (\%) & Result or status \\
\hline \multicolumn{10}{|c|}{ ANTI-ANGIOGENIC THERAPIES } \\
\hline Zalcman et al. (38) & NCT00651456 & MAPS & III & CT -/+ bevacizumab & 18.8 & 9.2 & NE & NE & Pos \\
\hline Tsao et al. (41) & NCT01064648 & SWOG S0905 & $\|$ & CT + ceradinib or pl. & 10.0 & 7.2 & 50.0 & NE & Neg \\
\hline Scagliotti et al. (43) & NCT01907100 & LUME-Meso & III & $\mathrm{CT}+$ nintedinab or pl. & 14.4 & 6.8 & 45.0 & 91.0 & Neg \\
\hline Buikhuisen et al. (44) & NCT01211275 & - & $\|$ & CT -/+ axitinib & 18.9 & 5.8 & 36.0 & 79.0 & Neg \\
\hline Dubey et al. (45) & NCT00107432 & - & $\|$ & Sorafenib & 9.7 & 3.6 & 6.0 & 60.0 & Neg \\
\hline Papa et al. (46) & NCT00794859 & SMS & $\|$ & Sorafenib & 9.0 & 5.1 & 6.0 & 62.0 & Neg \\
\hline van Brummelen et al. (47) & NCT01868022 & - & $\mathrm{lb}$ & GSK3052230 + CT & $\mathrm{NE}$ & 7.4 & 39.0 & 86.0 & Pos \\
\hline \multicolumn{10}{|c|}{ SYNTHETIC LETHALITY THERAPIES } \\
\hline \multirow[t]{2}{*}{ Beddowes et al. (49) } & NCT02029690 & TRAP & 1 & ADI-PEG $20+C T$ & 6.3 & 5.2 & 0 & 80.0 & $\begin{array}{l}\text { Pos (primary endpoints: } \\
\text { recommended dose, safety, } \\
\text { and tolerability) }\end{array}$ \\
\hline & NCT02709512 & ATOMIC-Meso & III & ADI-PEG 20 & - & - & - & - & Ongoing \\
\hline Zauderer et al. (61) & NCT02860286 & - & II & Tazemetostat & $\mathrm{NE}$ & $\mathrm{NE}$ & NE & 51.0 & Pos \\
\hline Fennell et al. (64) & NCT01870609 & COMMAND & ॥ & Defactinib or pl. & 12.7 & 4.1 & 18.0 & 64.0 & Neg \\
\hline \multicolumn{10}{|l|}{ IMMUNOTHERAPIES } \\
\hline Calabrò et al. (79) & NCT01649024 & MESOT-TREM-2008 & $\|$ & Tremelimumab & 10.7 & 6.2 & 7.0 & 31.0 & Neg \\
\hline Maio et al. (80) & NCT01843374 & DETERMINE & llb & Tremelimumab or pl. & 7.7 & 2.8 & 5.0 & 28.0 & Neg \\
\hline Quispel-Janssen et al. (81) & NCT02497508 & NivoMes & $\|$ & Nivolumab & 11.8 & 2.6 & 24.0 & 47.0 & Pos \\
\hline Okada et al. (82) & JapicCTI-163247 & MERIT & $\|$ & Nivolumab & 17.3 & 6.1 & 29.4 & NE & Pos \\
\hline Fennell et al. (83) & NCT03063450 & CONFIRM & III & Nivolumab or pl. & - & - & - & - & Ongoing \\
\hline Alley et al. (84) & NCT02054806 & KEYNOTE-028 & 1 & Pembrolizumab & 18.0 & 5.4 & 20.0 & 72.0 & Pos \\
\hline Desai et al. (85) & NCT02399371 & - & $\|$ & Pembrolizumab & 11.5 & 4.5 & 19.0 & 66.0 & Pos \\
\hline Popat et al. (87) & NCT02991482 & PROMISE-meso & III & Pembrolizumab vs. CT & 10.7 & 2.5 & 22.0 & & Neg \\
\hline Angevin et al. (88) & NCT02723955 & INDUCE-I & 1 & GSK3359609 & - & - & - & - & Ongoing \\
\hline Scherpereel et al. (89) & NCT02716272 & MAPS2 & $\|$ & Nivolumab vs. nivolumab + ipilumab & $11.9-15.9$ & $4.0-5.6$ & 19.0-28.0 & $44.0-50.0$ & Pos \\
\hline Zalcman et al. (90) & NCT02899299 & Checkmate 743 & III & Nivolumab + ipilumab vs. CT & - & - & - & - & Ongoing \\
\hline Calabrò et al. (91) & NCT02588131 & NIBIT-MESO-1 & $\|$ & Tremelimumab + durvalumab & 16.6 & 5.7 & 28.0 & 63.0 & Pos \\
\hline- & NCT02784171 & CCTG & III & $\begin{array}{l}\text { CT vs. CT + pembrolizumab vs. } \\
\text { pembrolizumab }\end{array}$ & - & - & - & - & Ongoing \\
\hline \multicolumn{10}{|l|}{ INNOVATIVE THERAPIES } \\
\hline van Zandwijk et al. (97) & NCT02369198 & MesomiR 1 & 1 & TargomiRs & 6.7 & $\mathrm{NE}$ & 5.0 & 73.0 & $\begin{array}{l}\text { Pos (primary endpoints: MTD } \\
\text { and DLT) }\end{array}$ \\
\hline Ceresoli et al. (99) & NCT02397928 & STELLAR & $\|$ & TTFields + CT & 18.2 & 7.6 & 40.0 & 97.0 & Pos \\
\hline \multicolumn{10}{|l|}{ ONCOVIRAL THERAPIES } \\
\hline Sterman et al. (101) & NCT01119664 & & $1 / / 1$ & $-1+\mathrm{CT}+\mathrm{rAd}-\mathrm{IFNa2b}+\mathrm{CT}$ & 21.5 & - & 25.0 & 88.0 & Pos (primary endpoint: safety) \\
\hline
\end{tabular}


TABLE 1 | Continued

\begin{tabular}{|c|c|c|c|c|c|c|c|c|c|}
\hline References & Clinical trial code & Acronymous & $\begin{array}{l}\text { Type of } \\
\text { study }\end{array}$ & Treatment & $\begin{array}{c}\text { OS } \\
\text { (months) }\end{array}$ & $\begin{array}{c}\text { PFS } \\
\text { (months) }\end{array}$ & ORR (\%) & DCR (\%) & Result or status \\
\hline & NCT03710876 & INFINITE & III & rAd-IFNa2b + celecoxib + gemcitabine & - & - & - & - & Ongoing \\
\hline Goto et al. (102) & UMIN000013568 & - & $1 / 11$ & Ad-SGE-REIC & & 3.4 & & 62.0 & $\begin{array}{l}\text { Pos (primary endpoints: safety } \\
\text { and tolerability) }\end{array}$ \\
\hline- & NCT04013334 & MTG201-MPM-001 & $\|$ & Ad-SGE-REIC + nivolumab & - & - & - & - & Ongoing \\
\hline Danson et al. (104) & NCT01721018 & - & l/lla & HSV-1716 & 15.0 & $\mathrm{NE}$ & $\mathrm{NE}$ & 50.0 & $\begin{array}{l}\text { Pos (primary endpoints: safety } \\
\text { and tolerability) }\end{array}$ \\
\hline- & NCT01503177 & - & 1 & Measles virus encoding NIS & 15.0 & 2.1 & 0 & 67.0 & $\begin{array}{l}\text { Pos (primary endpoint: AE } \\
\text { profile) }\end{array}$ \\
\hline \multicolumn{10}{|c|}{ DENDRITIC CELL VACCINATION } \\
\hline Cornelissen et al. (107) & NCT01241682 & PMR-MM-002 & 1 & Tumor lysate-pulsed DCV & $\mathrm{NE}$ & NE & $\mathrm{NE}$ & 80.0 & $\begin{array}{l}\text { Pos (primary endpoint: } \\
\text { number of cytotoxic } T \text { cells } \\
\text { and regulatory } T \text { cells in the } \\
\text { blood of patients) }\end{array}$ \\
\hline Belderbos et al. (108) & NCT03610360 & DENIM & $\|/\| \|$ & Tumor lysate-pulsed DCV + BSC vs. BSC & - & - & - & - & Ongoing \\
\hline Berneman et al. (109) & NCT01291420 & - & $1 / 11$ & WT1 DCV & 32.0 & 5.0 & $\mathrm{NE}$ & NE & $\begin{array}{l}\text { Pos (primary endpoint: } \\
\text { immunogenicity of intradermal } \\
\text { DCV) }\end{array}$ \\
\hline- & NCT02649829 & MESODEC & $\mid / I I$ & WT1 DCV + CT & - & - & - & - & Ongoing \\
\hline Doherty et al. (110) & NCT02414945 & TILs-003-Meso & $1 / 11$ & TILs + IL-2 & - & - & - & - & Ongoing \\
\hline- & NCT03546426 & MESOVAX & Ib & DCV + pembrolizumab & - & - & - & - & Ongoing \\
\hline \multicolumn{10}{|c|}{ ANTI-MSLN (IMMUNO)THERAPY } \\
\hline Hassan et al. (112) & NCT00738582 & - & $\|$ & Amatuximab + CT & 14.8 & 6.1 & 40.0 & 91.0 & Neg \\
\hline- & NCT02357147 & ARTEMIS & ॥ & Amatuximab + CT & - & - & - & - & $\begin{array}{l}\text { Terminated for business } \\
\text { reasons }\end{array}$ \\
\hline Blumenschein et al. (113) & NCT01439152 & - & 1 & AR & $\mathrm{NE}$ & $\mathrm{NE}$ & 31.0 & 75.0 & $\begin{array}{l}\text { Pos (primary endpoint: MTD } \\
\text { and pharmacokinetic profile) }\end{array}$ \\
\hline Kindler et al. (114) & NCT02610140 & - & $\|$ & AR or vinorelbine & 10.1 & 4.3 & 8.0 & NE & Neg \\
\hline- & NCT03126630 & MC1721 & $1 / I I$ & AR + pembrolizumab & - & - & - & - & Ongoing \\
\hline- & NCT02798536 & - & 1 & RG778/LMB-100 -/+ nab-paclitaxel & - & - & - & - & Ongoing \\
\hline Hassan et al. (116) & NCT01675765 & ADU-CL-02 & 1 & CRS-207 -/+ cyclophosphamide + CT & 14.7 & 7.5 & 54.0 & 89.0 & $\begin{array}{l}\text { Pos (primary endpoints: AE } \\
\text { profile and induction of an } \\
\text { immune response to MSLN) }\end{array}$ \\
\hline $\begin{array}{l}\text { Zhao et al. (118) and Beatty } \\
\text { et al. (119) }\end{array}$ & NCT01355965 & UPCC 17510 & 1 & MSLN-CAR-T (mouse scFv) & $\mathrm{NE}$ & $\mathrm{NE}$ & NE & NE & $\begin{array}{l}\text { Pos (primary endpoint: AE } \\
\text { profile) }\end{array}$ \\
\hline Adusumilli et al. $(122,123)$ & NCT02414269 & - & 1 & $\begin{array}{l}\text { MSLN-CAR-T (human scFv) + } \\
\text { pembrolizumab }\end{array}$ & - & - & - & - & Ongoing \\
\hline \multicolumn{10}{|c|}{ IMMUNOTHERAPIES AGAINST NON-MSLN TARGETS } \\
\hline Curioni et al. (125) & NCT01722149 & FAPME-1 & 1 & FAP-targeted CAR-T & $\mathrm{NE}$ & $\mathrm{NE}$ & $\mathrm{NE}$ & NE & Pos (primary endpoint: safety) \\
\hline Angevin et al. (128) & NCT03177668 & YS1101 & 1 & YS110 (anti-CD26) & 9.5 & 3.0 & 14.0 & 71.0 & Pos \\
\hline
\end{tabular}

OS, overall survival; PFS, progression-free survival; ORR, objective response rate; DCR, disease control rate; CT, chemotherapy; pl., placebo; NIS, sodium/iodide symporter; DCV, dendritic cell vaccination; BSC, best supportive care; WT1, Wilms' Tumor Antigen; TLLs, tumor-infiltrating lymphocytes; IL-2, interleukin-2; AR, Anetumab ravtansine; MSLN, mesothelin; CAR, chimeric antigen receptor; neg, negative; pos, positive; NE, not evaluated; MTD, maximum tolerated dose; DLT, dose-limiting toxicities; AE, adverse event; sCFv, single chain fragment variable. Primary endpoints are in bold or indicated in the last column. 
a good tolerance of treatment and persistence of CAR-T cells (125).

CD26 is a receptor overexpressed by all MPM histotypes and involved in immune regulation, T-cell activation, and the malignant potential of several cancers $(126,127)$. YS110 is a humanized mAb targeting CD26 that is currently under investigation in a phase I clinical trial (NCT03177668) in MPM patients. Preliminary results show that $50 \%$ $(13 / 26)$ of patients achieved SD, with a median PFS of 43 days $(128,129)$.

\section{DISCUSSION}

Despite amazing efforts devoted to understanding and treating MPM better (Figure 1 and Table 1), clinical practice has not changed over the past decades, and CT remains the only standard option. Anti-angiogenic therapies and also ICIs that showed impressive clinical responses in other solid malignancies have little impact on survival in MPM as single agents, while ICI combination efficiency comes at the cost of relevant toxicities. The hopes for patients with MPM are, therefore, innovative therapies such as oncoviral, TTFields, TargomiRs, and CAR therapies in combination with anti-PD-1 ICIs that have shown good preliminary efficacy, although the results need confirmation in larger trials.

\section{REFERENCES}

1. Carbone M, Adusumilli PS, Alexander HR Jr, Baas P, Bardelli F, Bononi A, et al. Mesothelioma: scientific clues for prevention, diagnosis, and therapy. CA A Cancer J Clin. (2019) 69:402-29. doi: 10.3322/caac.21572

2. Andujar P, Lacourt A, Brochard P, Pairon J-C, Jaurand M-C, Jean D. Five years update on relationships between malignant pleural mesothelioma and exposure to asbestos and other elongated mineral particles. J Toxicol Environ Health B Crit Rev. (2016) 19:151-72. doi: 10.1080/10937404.2016.1193361

3. Henley SJ, Larson TC, Wu M, Antao VCS, Lewis M, Pinheiro GA, et al. Mesothelioma incidence in 50 states and the District of Columbia, United States, 2003-2008. Int J Occup Environ Health. (2013) 19:110. doi: 10.1179/2049396712Y.0000000016

4. Yap TA, Aerts JG, Popat S, Fennel DA. Novel insights into mesothelioma biology and implications for therapy. Nature Reviews Cancer. (2017) 17:47588 doi: $10.1038 / \mathrm{nrc} .2017 .42$

5. Sato T, Sekido Y. NF2/Merlin inactivation and potential therapeutic targets in mesothelioma. Int J Mol Sci. (2018) 19:988-18. doi: 10.3390/ijms19040988

6. Batirel HF, Metintas M, Caglar HB, Yildizeli B, Lacin T, Bostanci K, et al. Trimodality treatment of malignant pleural mesothelioma. J Thorac Oncol. (2008) 3:499-504. doi: 10.1097/JTO.0b013e31816fcalb

7. Vogelzang NJ, Rusthoven JJ, Symanowski J, Denham C, Kaukel E, Ruffie P, et al. Phase III study of pemetrexed in combination with cisplatin versus cisplatin alone in patients with malignant pleural mesothelioma. J Clin Oncol. (2003) 21:2636-44. doi: 10.1200/JCO.2003.11.136

8. Baas P, Fennell D, Kerr KM, Van Schil PE, Haas RL, Peters S. Malignant pleural mesothelioma: ESMO clinical practice guidelines for diagnosis, treatment and follow-up. Ann Oncol. (2015) 26(suppl 5): v319. doi: 10.1093/annonc/mdv199

9. Scherpereel A, Astoul P, Baas P, Berghmans T, Clayson H, de Vuyst P, et al. Guidelines of the European Respiratory Society and the European Society of Thoracic Surgeons for the management of malignant pleural mesothelioma. Eur Respir J. (2010) 35: 479-95. doi: 10.1183/09031936.00063109

\section{AUTHOR CONTRIBUTIONS}

FN prepared the manuscript and figure. MM prepared part of the manuscript, provided guidance to $\mathrm{FN}$ in preparing the manuscript, and proofread and edited the manuscript. $\mathrm{MB}$, $\mathrm{GB}, \mathrm{AD}, \mathrm{MG}$, and $\mathrm{LC}$ helped with the review and made vital modifications along with suggestions to improve the content. All authors contributed to manuscript revision, read, and approved the submitted version.

\section{FUNDING}

Istituto Oncologico Romagnolo (IOR) and Becon AG through AFeVA, Associazione Familiari e Vittime Amianto, are funding our projects on malignant pleural mesothelioma. Neither of the funders contributed to the writing of this review.

\section{ACKNOWLEDGMENTS}

We thank Alicja M. Gruszka, MD Ph.D., for her help in proofreading and editing this manuscript. We also thank Istituto Oncologico Romagnolo (IOR) and Becon AG through AFeVA, Associazione Familiari e Vittime Amianto for funding our projects on malignant pleural mesothelioma.

10. van Zandwijk N, Clarke C, Henderson D, Musk AW, Fong K, Nowak A, et al. Guidelines for the diagnosis and treatment of malignant pleural mesothelioma. J Thorac Dis. (2013) 5:E254-307. doi: 10.3978/j.issn.2072-1439.2013.11.28

11. Lang-Lazdunski L, Bille A, Lal R, Cane P, McLean E, Landau $\mathrm{D}$, et al. Pleurectomy/decortication is superior to extrapleural pneumonectomy in the multimodality management of patients with malignant pleural mesothelioma. J Thorac Oncol. (2012) 7:737-43. doi: 10.1097/JTO.0b013e31824ab6c5

12. Sugarbaker DJ, Richards WG, Bueno R. Extrapleural pneumonectomy in the treatment of epithelioid malignant pleural mesothelioma: novel prognostic implications of combined N1 and N2 nodal involvement based on experience in 529 patients. Ann Surg. (2014) 260:577-80. discussion: 580-2. doi: 10.1097/SLA.0000000000000903

13. Treasure T, Lang-Lazdunski L, Waller D, Bliss JM, Tan C, Entwisle J, et al. Extra-pleural pneumonectomy versus no extra-pleural pneumonectomy for patients with malignant pleural mesothelioma: clinical outcomes of the Mesothelioma and Radical Surgery (MARS) randomised feasibility study. Lancet Oncol. (2011) 12:763-72. doi: 10.1016/S1470-2045(11)70149-8

14. Friedberg JS, Simone CB 2nd, Culligan MJ, Barsky AR, Doucette A, McNulty $\mathrm{S}$, et al. Extended pleurectomy-decortication-based treatment for advanced stage epithelial mesothelioma yielding a median survival of nearly three years. Ann Thorac Surg. (2017) 103:912-9. doi: 10.1016/j.athoracsur.2016.08.071

15. Zhao ZY, Zhao SS, Ren M, Liu ZL, Li Z, Yang L Effect of hyperthermic intrathoracic chemotherapy on the malignant pleural mesothelioma: a systematic review and meta-analysis. Oncotarget. (2017) 8:1006407. doi: 10.18632 /oncotarget. 22062

16. Lang-Lazdunski L, Bille A, Belcher E, Cane P, Landau D, Steele J, et al. Pleurectomy/decortication, hyperthermic pleural lavage with povidone-iodine followed by adjuvant chemotherapy in patients with malignant pleural mesothelioma. J Thorac Oncol. (2011) 6:1746-52. doi: 10.1097/JTO.0b013e3182288af9 
17. Opitz I, Lauk O, Meerang M, Jetter A, Aeschlimann B, Seifert B, et al. Intracavitary cisplatin-fibrin chemotherapy after surgery for malignant pleural mesothelioma - a phase I trial. J Thorac Cardiovasc Surg. (2019) 159:330-340.e4. doi: 10.1016/j.jtcvs.2019.07.073

18. Krug LM, Pass HI, Rusch VW, Kindler HL, Sugarbaker DJ, Rosenzweig KE, et al. Multicenter phase II trial of neoadjuvant pemetrexed plus cisplatin followed by extrapleural pneumonectomy and radiation for malignant pleural mesothelioma. J Clin Oncol. (2009) 27:3007-13. doi: 10.1200/JCO.2008.20.3943

19. Rusch VW, Rosenzweig K, Venkatraman E, Leon L, Raben A, Harrison $\mathrm{L}$, et al. A phase II trial of surgical resection and adjuvant high-dose hemithoracic radiation for malignant pleural mesothelioma. J Thorac Cardiovasc Surg. (2001) 122:788-95. doi: 10.1067/mtc.2001.116560

20. Cho BC, Feld R, Leighl N, Opitz I, Anraku M, Tsao MS, et al. A feasibility study evaluating surgery for mesothelioma after radiation therapy: the "SMART" approach for resectable malignant pleural mesothelioma. J Thorac Oncol. (2014) 9:397-402. doi: 10.1097/JTO.0000000000000078

21. de Perrot M, Feld R, Leighl NB, Hope A, Waddell TK, Keshavjee $S$, et al. Accelerated hemithoracic radiation followed by extrapleural pneumonectomy for malignant pleural mesothelioma. J Thorac Cardiovasc Surg. (2016) 151:468-73. doi: 10.1016/j.jtcvs.2015.09.129

22. Nelson DB, Rice DC, Mitchell KG, Tsao AS, Gomez DR, Sepesi $B$, et al. Return to intended oncologic treatment after surgery for malignant pleural mesothelioma. J Thorac Cardiovasc Surg. (2019) 158:9249. doi: 10.1016/j.jtcvs.2019.02.129

23. Clive AO, Taylor H, Dobson L, Wilson P, de Winton E, Panakis $\mathrm{N}$, et al. Prophylactic radiotherapy for the prevention of proceduretract metastases after surgical and large-bore pleural procedures in malignant pleural mesothelioma (SMART): a multicentre, open-label, phase 3, randomised controlled trial. Lancet Oncol. (2016) 17:1094-104. doi: 10.1016/S1470-2045(16)30095-X

24. Bayman N, Appel W, Ashcroft L, Baldwin DR, Bates A, Darlison L, et al. Prophylactic irradiation of tracts in patients with malignant pleural mesothelioma: an open-label, multicenter, phase III randomized trial. J Clin Oncol. (2019) 37:1200-8. doi: 10.1200/JCO.18.01678

25. Kindler HL, Ismailia N, Armato 3rd SG, Bueno R, Hesdorffer M, Jahan T, et al. Treatment of malignant pleural mesothelioma: ASCO clinical practice guidelines. JCO. (2018) 36:1343-73. doi: 10.1200/JCO.2017.76.6394

26. Minatel E, Trovo M, Bearz A, Di Maso M, Baresic T, Drigo A, et al. Radical radiation therapy after lung-sparing surgery for malignant pleural mesothelioma: survival, pattern of failure, and prognostic factors. Int J Radiat Oncol Biol Phys. (2015) 93:606-13. doi: 10.1016/j.ijrobp.2015.06.029

27. Rimner A, Zauderer MG, Gomez DR, Adusumilli PS, Parhar PK, Wu J, et al. Phase II study of hemithoracic intensity-modulated pleural radiation therapy (IMPRINT) as part of lung-sparing multimodality therapy in patients with malignant pleural mesothelioma. J Clin Oncol. (2016) 34:27618. doi: 10.1200/JCO.2016.67.2675

28. Rosenzweig KE, Zauderer MG, Laser B, Krug LM, Yorke E, Sima $\mathrm{CS}$, et al. Pleural intensity-modulated radiotherapy for malignant pleural mesothelioma. Int $J$ Radiat Oncol Biol. Phys. (2012) 83:1278-83. doi: 10.1016/j.ijrobp.2011.09.027

29. Pan HY, Jiang S, Sutton J, Liao Z, Chance WW, Frank SJ, et al. Early experience with intensity modulated proton therapy for lungintact mesothelioma: a case series. Pract Radiat Oncol. (2015) 5:e34553. doi: 10.1016/j.prro.2014.11.005

30. Dumane VA, Rimner A, Yorke ED, Rosenzweig KE. Volumetricmodulated arc therapy for malignant pleural meso- thelioma after pleurectomy/decortication. Appl Rad Oncol. (2016) 5:28-37.

31. Campbell NP, Kunnavakkam R, Leighl N, Vincent MD, Gandara DR, Koczywas M, et al. Cediranib in patients with malignant mesothelioma: a phase II trial of the University of Chicago Phase II Consortium. Lung Cancer. (2012) 78:76-80. doi: 10.1016/j.lungcan.2012.06.011

32. Garland LL, Chansky K, Wozniak AJ, Tsao AS, Gadgeel SM, Verschraegen $\mathrm{CF}$, et al. Phase II study of cediranib in patients with malignant pleural mesothelioma: SWOG S0509. J Thorac Oncol. (2011) 6:193845. doi: 10.1097/JTO.0b013e318229586e

33. Laurie SA, Hao D, Leighl NB, Goffin J, Khomani A, Gupta A, et al. A phase II trial of dovitinib in previously-treated advanced pleural mesothelioma: the Ontario Clinical Oncology Group. Lung Cancer. (2017) 104:659. doi: 10.1016/j.lungcan.2016.12.004

34. Laurie SA, Gupta A, Chu Q, Lee CW, Morzycki W, Feld R, et al. Brief report: a phase II study of sunitinib in malignant pleural mesothelioma. The NCIC Clinical Trials Group. J Thorac Oncol. (2011) 6:19504. doi: 10.1097/JTO.0b013e3182333df5

35. Nowak AK, Millward MJ, Creaney J, Francis RJ, Hasani A, van der Schaaf A, et al. A phase II study of intermittent sunitinib malate as second-line therapy in progressive malignant pleural mesothelioma. J Thorac Oncol. (2012) 7:1449-56. doi: 10.1097/JTO.0b013e31825 f22ee

36. Baas P, Boogerd W, Dalesio O, Haringhuizen A, Custers F, van Zandwijk N. Thalidomide in patients with malignant pleural mesothelioma. Lung Cancer. (2005) 48:291-6. doi: 10.1016/j.lungcan.2004.10.005

37. Jahan T, Gu L, Kratzke R, Dudek A, Otterson GA, Wang X, et al. Vatalanib in malignant mesothelioma: a phase II trial by the Cancer and Leukemia Group B (CALGB 30107). Lung Cancer. (2012) 76:3936. doi: 10.1016/j.lungcan.2011.11.014

38. Zalcman G, Mazieres J, Margery J, Greillier L, Audigier-Valette C, MoroSibilot D, et al. Bevacizumab for newly diagnosed pleural mesothelioma in the Mesothelioma Avastin Cisplatin Pemetrexed Study (MAPS): a randomised, controlled, open-label, phase 3 trial. Lancet. (2016) 387:140514. doi: 10.1016/S0140-6736(15)01238-6

39. Ettinger DS, Wood DE, Akerley W, Bazhenova LA, Borghaei H, Camidge DR, et al. NCCN guidelines insights: malignant pleural mesothelioma, version 3.2016. J Natl Compr Canc Netw. (2016) 14:82536. doi: 10.6004/jnccn.2016.0087

40. Tsao AS, Moon J, Wistuba II, Vogelzang NJ, Kalemkerian GP, Redman MW, et al. Phase I trial of cediranib in combination with cisplatin and pemetrexed in chemonaive patients with unresectable malignant pleural mesothelioma (SWOG S0905). J Thorac Oncol. (2017) 12:1299308. doi: 10.1016/j.jtho.2017.05.021

41. Tsao AS, Miao J, Wistuba II, Vogelzang NJ, Heymach JV, Fossella $\mathrm{FV}$, et al. Phase II trial of cediranib in combination with cisplatin and pemetrexed in chemotherapy-naive patients with unresectable malignant pleural mesothelioma (SWOG S0905). J Clin Oncol. (2019) 37:JCO1900269. doi: 10.1200/JCO.19.00269

42. Grosso F, Steele N, Novello S, Nowak AK, Popat S, Greillier L, et al. Nintedanib plus pemetrexed/cisplatin in patients with malignant pleural mesothelioma: phase II results from the randomized, placebo-controlled LUME-Meso trial. J Clin Oncol. (2017) 35:3591-600. doi: 10.1200/JCO.2017.72.9012

43. Scagliotti GV, Gaafar R, Nowak AK, Nakano T, van Meerbeeck J, Popat S, et al. Nintedanib in combination with pemetrexed and cisplatin for chemotherapy-naive patients with advanced malignant pleural mesothelioma (LUME-Meso): a double-blind, randomised, placebo-controlled phase 3 trial. Lancet Respir Med. (2019) 7:569-80. doi: 10.1016/S2213-2600(19)30139-0

44. Buikhuisen WA, Scharpfenecker M, Griffioen AW, Korse CM, van Tinteren H, Bas P. A randomized phase 2 study adding axitinib to pemetrexedcisplatin in patients with malignant pleural mesothelioma: a single-center trial combining clinical and translational outcomes. J Thorac Oncol. (2016) 11:758-68. doi: 10.1016/j.jtho.2016.01.014

45. Dubey S, Jänne PA, Krug L, Pang H, Wang X, Heinze R, et al. A phase II study of sorafenib in malignant mesothelioma: results of Cancer and Leukemia Group B 30307. J Thorac Oncol. (2010) 5:165561. doi: 10.1097/JTO.0b013e3181ec18db

46. Papa S, Popat S, Shah R, Prevost AT, Lal R, McLennan B, et al. Phase 2 study of sorafenib in malignant mesothelioma previously treated with platinum-containing chemotherapy. J Thorac Oncol. (2013) 8:7837. doi: $10.1097 / J T O .0 b 013 \mathrm{e} 31828 \mathrm{c} 2 \mathrm{~b} 26$

47. van Brummelen EMJ, Levchenko E, Dómine M, Fennell DA, Kindler HL, Viteri S, et al. A phase Ib study of GSK3052230, an FGF ligand trap in combination with pemetrexed and cisplatin in patients with malignant pleural mesothelioma. Invest New Drugs. (2019) 17:47511. doi: 10.1007/s10637-019-00783-7

48. Locke M, Ghazaly E, Freitas MO, Mitsinga M, Lattanzio L, Lo Nigro $\mathrm{C}$, et al. Inhibition of the polyamine synthesis pathway is synthetically 
lethal with loss of argininosuccinate synthase 1. Cell Rep. (2016) 16:160413. doi: $10.1016 /$ j.celrep.2016.06.097

49. Beddowes E, Spicer J, Chan PY, Khadeir R, Corbacho JG, Repana $\mathrm{D}$, et al. Phase 1 dose-escalation study of pegylated arginine deiminase, cisplatin, and pemetrexed in patients with argininosuccinate synthetase 1-deficient thoracic cancers. J Clin Oncol. (2017) 35:1778-85. doi: 10.1200/JCO.2016.71.3230

50. Yu H, Pak H, Hammond-Martel I, Ghram M, Rodrigue A, Daou S, et al. Tumour suppressor and deubiquitinase BAP1 promotes DNA double-strand break repair. Proc Natl Acad Sci USA. (2014) 111:28590. doi: 10.1073/pnas.1309085110

51. Bononi A, Giorgi C, Patergnani S, Larson D, Verbruggen K, Tanji M, et al. BAP1 regulates IP3R3-mediated $\mathrm{Ca}(2+)$ flux to mitochondria suppressing cell transformation. Nature. (2017) 546:549-53. doi: 10.1038/nature22798

52. Guazzelli A, Meysami P, Bakker E, Demonacos C, Giordano A, KrsticDemonacos M, et al. BAP1 status determines the sensitivity of malignant mesothelioma cells to gemcitabine treatment. Int J Mol Sci. (2019) 20:42913. doi: 10.3390/ijms20020429

53. Kumar N, Alrifai D, Kolluri KK, Sage EK, Ishii Y, Guppy N, et al. Retrospective response analysis of BAP1 expression to predict the clinical activity of systemic cytotoxic chemotherapy in mesothelioma. Lung Cancer. (2019) 127:164-6. doi: 10.1016/j.lungcan.2018.12.004

54. Testa JR, Cheung M, Pei J, Below JE, Tan Y, Sementino E, et al. Germline BAP1 mutations predispose to malignant mesothelioma. Nat Genet. (2011) 43:1022-5. doi: 10.1038/ng.912

55. Betti M, Aspesi A, Biasi A, Casalone E, Ferrante D, Ogliara P, et al. CDKN2A and BAP1 germline mutations predispose to melanoma and mesothelioma. Cancer Lett. (2016) 378:120-30. doi: 10.1016/j.canlet.2016.05.011

56. Abdel-Rahman MH, Pilarski R, Cebulla CM, Massengill JB, Christopher BN, Boru G, et al. Germline BAP1 mutation predisposes to uveal melanoma, lung adenocarcinoma, meningioma, and other cancers. J Med Genet. (2011) 48:856-9. doi: 10.1136/jmedgenet-2011-100156

57. Hassan R, Morrow B, Thomas A, Walsh T, Lee MK, Gulsuner S, et al. Inherited predisposition to malignant mesothelioma and overall survival following platinum chemotherapy. Proc Natl Acad Sci USA. (2019) 116:900813. doi: $10.1073 /$ pnas. 1821510116

58. Srinivasan G, Sidhu GS, Williamson EA, Jaiswal AS, Najmunnisa N, Wilcoxen K. Synthetic lethality in malignant pleural mesothelioma with PARP1 inhibition. Cancer Chemother Pharmacol. (2017) 80:8617. doi: $10.1007 / \mathrm{s} 00280-017-3401-y$

59. LaFave LM, Beguelin W, Koche R, Teater M, Spitzer B, Chramiec A, et al. Loss of BAP1 function leads to EZH2-dependent transformation. Nat Med. (2015) 21:1344-9. doi: 10.1038/nm.3947

60. Marchesi I, Bagella L. Targeting enhancer of zeste homolog 2 as a promising strategy for cancer treatment. World J Clin Oncol. (2016) 7:135. doi: 10.5306/wjco.v7.i2.135

61. Zauderer MG, Szlosarek P, Le Moulec S, Popat S, Taylor P, Planchard D, et al. Phase 2, multicenter study of the EZH2 inhibitor tazemetostat as monotherapy in adults with relapsed or refractory (R/R) malignant mesothelioma (MM) with BAP1 inactivation. JCO. (2018) 36(15_suppl):8515. doi: 10.1200/JCO.2018.36.15_suppl.8515

62. Lee BY, Timpson P, Horvath LG, Daly RJ. FAK signaling in human cancer as a target for therapeutics. Pharmacol Ther. (2015) 146:13249. doi: 10.1016/j.pharmthera.2014.10.001

63. Soria JC, Gan HK, Blagden SP, Plummer R, Arkenau HT, Ranson M, et al. A phase I, pharmacokinetic and pharmacodynamic study of GSK2256098, a focal adhesion kinase inhibitor, in patients with advanced solid tumours. Ann Oncol. (2016) 27:2268-74. doi: 10.1093/annonc/mdw427

64. Fennell DA, Baas P, Taylor P, Nowak A, Gilligan D, Nakano T, et al. Maintenance defactinib versus placebo after first-line chemotherapy in patients with merlin-stratified pleural mesothelioma: COMMANDa double-blind, randomized, phase II study. JCO. (2019) 37:7908. doi: $10.1200 /$ JCO.2018.79.0543

65. Chee SJ, Lopez M, Mellows T, Gankande S, Moutasim KA, Harris S, et al. Evaluating the effect of immune cells on the outcome of patients with mesothelioma. Br J Cancer. (2017) 117:1341-8. doi: 10.1038/bjc.2017.269

66. Ye L, Ma S, Robinson BW, Creaney J. Immunotherapy strategies for mesothelioma - the role of tumor specific neoantigens in a new era of precision medicine. Expert Rev Respir Med. (2019) 13:18192. doi: 10.1080/17476348.2019.1563488

67. Moser JC, Peikert T, Roden AC, Midthun DE, Mansfield AS. Spontaneous regression of malignant pleural mesothelioma in a patient with newonset inflammatory arthropathy. Ann Am Thorac Soc. (2015) 12:14167. doi: 10.1513/AnnalsATS.201506-315LE

68. Robinson BW, Robinson C, Lake RA. Localised spontaneous regression in mesothelioma-possible immunological mechanism. Lung Cancer. (2001) 32:197-201. doi: 10.1016/S0169-5002(00)00217-8

69. Krishnan S, Bakker E, Lee C, Kissick HT, Ireland DJ, Beilharz MW. Successful combined intratumoural immunotherapy of established murine mesotheliomas requires B-cell involvement. J Interferon Cytokine Res. (2015) 35:100-7. doi: 10.1089/jir.2014.0054

70. Anraku M, Cunningham KS, Yun Z, Tsao MS, Zhang L, Keshavjee S, et al. Impact of tumour-infiltrating $\mathrm{T}$ cells on survival in patients with malignant pleural mesothelioma. J Thorac Cardiovasc Surg. (2008) 135:82339. doi: $10.1016 /$ j.jtcvs.2007.10.026

71. Yamada N, Oizumi S, Kikuchi E, Shinagawa N, Konishi-Sakakibara J, Ishimine A, et al. CD8+ tumour- infiltrating lymphocytes predict favorable prognosis in malignant pleural mesothelioma after resection. Cancer Immunol Immunother. (2010) 59:1543-9. doi: 10.1007/s00262-010-0881-6

72. Gibbons Johnson RM, Dong H. Functional expression of programmed death-ligand 1 (B7-H1) by immune cells and tumour cells. Front Immunol. (2017) 8:961. doi: 10.3389/fimmu.2017.00961

73. Mansfield AS, Roden AC, Peikert T, Sheinin YM, Harrington SM, Krco CJ, et al. B7-H1 expression in malignant pleural mesothelioma is associated with sarcomatoid histology and poor prognosis. J Thorac Oncol. (2014) 9:1036-40. doi: 10.1097/JTO.0000000000000177

74. Terra SBSP, Mansfield AS, Dong H, Peikert T, Roden AC. Temporal and spatial heterogeneity of programmed cell death 1-ligand 1 expression in malignant mesothelioma. Oncoimmunology. (2017) 6:e1356146. doi: 10.1080/2162402X.2017.1356146

75. Sepesi B, IconTeam, Heymach J, Sharma P, Allison J, Fang B, et al. OA20.06 prospective immunogenomic profiling of nonsmall cell lung cancer - The ICON Project. J Thorac Oncol. (2017) 12:S324-5. doi: 10.1016/j.jtho.2016.11.347

76. Balar AV, Weber J. PD-1 and PD-L1 antibodies in cancer: current status and future directions. Cancer Immunol Immunother. (2017) 66:55164. doi: 10.1007/s00262-017-1954-6

77. Lievense LA, Sterman DH, Cornelissen R, Aerts JG. Checkpoint blockade in lung cancer and mesothelioma. Am J Respir Crit Care Med. (2017) 196:274-82. doi: 10.1164/rccm.201608-1755CI

78. Kyi C, Postow MA. Immune checkpoint inhibitor combinations in solid tumours: opportunities and challenges. Immunotherapy. (2016) 8:82137. doi: $10.2217 / \mathrm{imt}-2016-0002$

79. Calabrò L, Morra A, Fonsatti E, Cutaia O, Amato G, Giannarelli D, et al. Tremelimumab for patients with chemotherapy-resistant advanced malignant mesothelioma: an open-label, single-arm, phase 2 trial. Lancet Oncol. (2013) 14:1104-11. doi: 10.1016/S1470-2045(13)70381-4

80. Maio M, Scherpereel A, Calabrò L, Aerts J, Cedres Perez S, Bearz A, et al. Tremelimumab as second-line or third-line treatment in relapsed malignant mesothelioma (DETERMINE): a multicentre, international, randomised, double-blind, placebo-controlled phase $2 \mathrm{~b}$ trial. Lancet Oncol. (2017) 18:1261-73. doi: 10.1016/S1470-2045(17)30446-1

81. Quispel-Janssen J, Zago G, Schouten R, Buikhuisen W, Monkhorst K Thunissen E, et al. OA13.01 a phase II study of nivolumab in malignant pleural mesothelioma (NivoMes): with translational research (TR) biopies. J Thorac Oncol. (2017) 12:S292-3. doi: 10.1016/j.jtho.2016.11.300

82. Okada M, Kijima T, Aoe K, Kato T, Fujimoto N, Nakagawa K, et al. Clinical efficacy and safety of nivolumab: results of a multicenter, openlabel, single-arm, Japanese Phase II study in Malignant Pleural Mesothelioma (MERIT). Clin Cancer Res. (2019) 25:5485-92. doi: 10.1158/1078-0432.CCR19-0103

83. Fennell DA, Kirkpatrick E, Cozens K, Nye M, Lester J, Hanna G, et al. CONFIRM: a double-blind, placebo- controlled phase III clinical trial investigating the effect of nivolumab in patients with relapsed mesothelioma: study protocol for a randomised controlled trial. Trials. (2018) 19:233. doi: 10.1186/s13063-018-2602-y 
84. Alley EW, Lopez J, Santoro A, Morosky A, Saraf S, Piperdi B, et al. Clinical safety and activity of pembrolizumab in patients with malignant pleural mesothelioma (KEYNOTE-028): preliminary results from a nonrandomised, open-label, phase 1b trial. Lancet Oncol. (2017) 18:62330. doi: 10.1016/S1470-2045(17)30169-9

85. Desai A, Karrison T, Rose B, Tan Y, Hill B, Pemberton E, et al. OA08.03 phase II trial of pembrolizumab (NCT02399371) in previously-treated malignant mesothelioma (MM): final analysis. J Thorac Oncol. (2018) 13:S339. doi: 10.1016/j.jtho.2018.08.277

86. Metaxas Y, Rivalland G, Mauti LA, Klingbiel D, Kao S, Schmid S, et al. Pembrolizumab as palliative immunotherapy in malignant pleural mesothelioma. J Thorac Oncol. (2018) 13:1784-91. doi: 10.1016/j.jtho.2018.08.007

87. Popat S, Curioni-Fontecedro A, Polydoropoulou V, Shah R, O’Brien M, Pope A, et al. LBA91_PRA multicentre randomized phase III trial comparing pembrolizumab (P) vs single agent chemotherapy (CT) for advanced pretreated malignant pleural mesothelioma (MPM): results from the european thoracic oncology platform (ETOP 9-15) PROMISE-meso trial. Annonc. (2019) 30:v931. doi: 10.1093/annonc/mdz394.091

88. Angevin E, Bauer TM, Ellis CE, Gan H, Hall R, Hansen A, et al. Abstract CT039: INDUCE-1: a phase I open-label study of GSK3359609, an ICOS agonist antibody, administered alone and in combination with pembrolizumab in patients with selected, advanced solid tumors. Cancer Res. (2017) 77:CT039. doi: 10.1158/1538-7445.AM2017-CT039

89. Scherpereel A, Mazieres J, Greillier L, Dô P, Bylicki O, Monnet I, et al. Second- or third-line nivolumab (Nivo) versus nivo plus ipilimumab (Ipi) in malignant pleural mesothelioma (MPM) patients: Results of the IFCT-1501 MAPS2 randomized phase II trial. JCO. (2017) 35:LBA8507. doi: 10.1200/JCO.2017.35.18_suppl.LBA8507

90. Zalcman G, Peters S, Mansfield AS, Jahan TM, Popat S, Scherpereel A, et al. Checkmate 743: A phase 3, randomized, open-label trial of nivolumab (nivo) plus ipilimumab (ipi) vs pemetrexed plus cisplatin or carboplatin as first-line therapy in unresectable pleural mesothelioma. JCO. (2017) 35(15_suppl):TPS8581. doi: 10.1200/JCO.2017.35.15_suppl.TPS8581

91. Calabrò L, Morra A, Giannarelli D, Amato G, D'Incecco A, Covre $A$, et al. Tremelimumab in combination with durvalumab in first or second-line mesothelioma patients: safety analysis from the phase II NIBIT-MESO-1 study. Lancet Respir Med. (2018) 6:451-60. doi: 10.1016/S2213-2600(18)30151-6

92. Chung HJ, Choi YE, Kim ES, Han YH, Park MJ, Bae IH. miR$29 \mathrm{~b}$ attenuates tumourigenicity and stemness maintenance in human glioblastoma multiforme by directly targeting BCL2L2. Oncotarget. (2015) 6:18429-44. doi: 10.18632/oncotarget.4384

93. Yang L, Li C, Liang F, Fan Y, Zhang S. MiRNA-155 promotes proliferation by targeting caudal-type homeobox 1 (CDX1) in glioma cells. Biomed Pharmacother. (2017) 95:1759-64. doi: 10.1016/j.biopha.2017.08.088

94. Mendell, JT. miRiad roles for the miR-17-92 cluster in development and disease. Cell. (2008) 133:217-22. doi: 10.1016/j.cell.2008.04.001

95. Reid G, Pel Me, Kirschner MB, Cheng YY, Mugridge N, Weiss J, et al. Restoring expression of miR-16: a novel approach to therapy for malignant pleural mesothelioma. Ann Oncol. (2013) 24:3128-35. doi: 10.1093/annonc/mdt412

96. MacDiarmid JA, Mugridge NB, Weiss JC, Phillips L, Burn AL, Paulin $\mathrm{RP}$, et al. Bacterially derived $400 \mathrm{~nm}$ particles for encapsulation and cancer cell targeting of chemotherapeutics. Cancer Cell. (2007) 11:43145. doi: 10.1016/j.ccr.2007.03.012

97. van Zandwijk N, Pavlakis N, Kao SC, Linton A, Boyer MJ, Clarke $S$, et al. Safety and activity of microRNA-loaded minicells in patients with recurrent malignant pleural mesothelioma: a first-in-man, phase 1, open-label, dose-escalation study. Lancet Oncol. (2017) 18:138696. doi: 10.1016/S1470-2045(17)30621-6

98. Weinberg U, Munster M, Gotlib K, Schneiderman RS, Porat Y, Voloshin T, et al. The combined treatment of $150 \mathrm{kHz}$ tumor treating fields (TTFields) and cisplatin or pemetrexed inhibits mesothelioma cells in vitro and in vivo. JCO. (2019) 37:e20069. doi: 10.1200/JCO.2019.37.15_suppl.e15653

99. Ceresoli G, Aerts J, Madrzak J, Dziadziuszko R, Ramlau R, Cedres S, et al. MA12.06 STELLAR - final results of a phase 2 trial of TTFields with chemotherapy for first-line treatment of malignant pleural mesothelioma. $J$ Thorac Oncol. (2018) 13:S397-8. doi: 10.1016/j.jtho.2018.08.416

100. Sterman DH, Haas A, Moon E, Recio A, Schwed D, Vachani A, et al. A trial of intrapleural adenoviral-mediated Interferon- $\alpha 2 b$ gene transfer for malignant pleural mesothelioma. Am J Respir Crit Care Med. (2011) 184:1395-9. doi: 10.1164/rccm.201103-0554CR

101. Sterman DH, Alley E, Stevenson JP, Friedberg J, Metzger S, Recio $A$, et al. Pilot and feasibility trial evaluating immuno-gene therapy of malignant mesothelioma using intrapleural delivery of adenovirusIFN $\alpha$ combined with chemotherapy. Clin Cancer Res. (2016) 22:3791800. doi: 10.1158/1078-0432.CCR-15-2133

102. Goto Y, Ohe Y, Kuribayashi K, Nakano T, Okada M, Toyooka S, et al. P2.06-11 a phase I/II study of intrapleural Ad-SGE-REIC administration in patients with refractory malignant pleural mesothelioma. J Thorac Oncol. 13:S746. doi: 10.1016/j.jtho.2018.08.1266

103. Kucharczuk JC, Randazzo B, Chang MY, Amin KM, Elshami AA, Sterman $\mathrm{DH}$, et al. Use of a "replication-restricted" herpes virus to treat experimental human malignant mesothelioma. Cancer Res. (1997) 57:466-71.

104. Danson S, Woll P, Edwards J, Blyth K, Fisher P, Roman J, et al. 366PDOncolytic herpesvirus therapy for mesothelioma: a phase I/IIa trial of intrapleural administration of HSV1716 (NCT01721018). Annonc. (2017) 28:v122-41. doi: 10.1093/annonc/mdx367.001

105. Pease DF, Kratzke RA. Oncolytic viral therapy for mesothelioma. Front Oncol. (2017) 7:525-15. doi: 10.3389/fonc.2017.00179

106. Palucka K, Banchereau J. Cancer immunotherapy via dendritic cells. Nat Rev Cancer. (2012) 12:265-77. doi: 10.1038/nrc3258

107. Cornelissen R, Hegmans JP, Maat AP, Kaijen-Lambers ME, Bezemer K, Hendriks RW, et al. Extended tumour control after dendritic cell vaccination with low-dose cyclophosphamide as adjuvant treatment in patients with malignant pleural mesothelioma. Am J Respir Crit Care Med. (2016) 193:1023-31. doi: 10.1164/rccm.201508-1573OC

108. Belderbos RA, Baas P, Berardi R, Cornelissen R, Fennell DA, van Meerbeeck JP, et al. A multicenter, randomized, phase II/III study of dendritic cells loaded with allogeneic tumor cell lysate (MesoPher) in subjects with mesothelioma as maintenance therapy after chemotherapy: DENdritic cell Immunotherapy for Mesothelioma (DENIM) trial. Transl Lung Cancer Res. (2019) 8:280-5. doi: 10.21037/tlcr.2019.05.05

109. Berneman ZN, Van de Velde AL, Willemen Y, Anguille S, Saevels K, Germonpré P, et al. Vaccination with WT1 mRNA-electroporated dendritic cells: report of clinical outcome in 66 cancer patients. Blood. (2014) 124:310. doi: 10.1182/blood.V124.21.310.310

110. Doherty M, Leighl NB, Feld R, Bradbury PA, Wang L, Nie $\mathrm{P}$, et al. Phase I/II study of tumour-infiltrating lymphocyte (TIL) infusion and low-dose interleukin-2 (IL-2) in patients with advanced malignant pleural mesothelioma (MPM). JCO. (2015) 33(15_suppl):TPS7586. doi: 10.1200/jco.2015.33.15_suppl. tps7586

111. Lv J, Li P. Mesothelin as a biomarker for targeted therapy. Biomark Res. (2019) 7:18. doi: 10.1186/s40364-019-0169-8

112. Hassan R, Kindler HL, Jahan T, Bazhenova L, Reck M, Thomas A, et al. Phase II clinical trial of amatuximab, a chimeric antimesothelin antibody with pemetrexed and cisplatin in advanced unresectable pleural mesothelioma. Clin Cancer Res. (2014) 20:5927-36. doi: 10.1158/1078-0432.CCR14-0804

113. Blumenschein GR, Hassan R, Moore KN, Santin A, Kindler HL, Nmunaitis JL, et al. Phase I study of anti-mesothelin antibody-drug conjugate anetumab ravtansine (AR). J Clin Oncol. (2016) 34:abstr 2509. doi: 10.1200/JCO.2016.34.15_suppl.2509

114. Kindler HL, Novello S, Fennell D, Blumenschein G, Bearz A, Ceresoli G, et al. OA 02.01 randomized phase II study of anetumab ravtansine or vinorelbine in patients with metastatic pleural mesothelioma. J Thorac Oncol. 12:S1746. doi: 10.1016/j.jtho.2017.09.328

115. Zhang J, Khanna S, Jiang Q, Alewine C, Miettinen M, Pastan I, Hassan R. Efficacy of anti-mesothelin immunotoxin RG7787 plus Nabpaclitaxel against mesothelioma patient-derived xenografts and mesothelin as a biomarker of tumor response. Clin Cancer Res. (2017) 23:156474. doi: 10.1158/1078-0432.CCR-16-1667 
116. Hassan R, Alley E, Kindler H, Antonia S, Jahan T, Honarmand S, et al. Liveattenuated, Listeria monocytogenes expressing mesothelin (CRS-207) with chemotherapy for treatment of malignant pleural mesothelioma. Clin Cancer Res. (2019) 25:5787. doi: 10.1158/1078-0432.CCR-19-0070

117. Zeltsman M, Dozier J, McGee E, Ngai D, Adusumilli PS. CAR T-cell therapy for lung cancer and malignant pleural mesothelioma. Transl Res. (2017) 187:1-10. doi: 10.1016/j.trsl.2017.04.004

118. Zhao Y, Moon E, Carpenito C, Paulos CM, Liu X, Brennan AL, et al. Multiple injections of electroporated autologous $\mathrm{T}$ cells expressing a chimeric antigen receptor mediate regression of human disseminated tumour. Cancer Res. (2010) 70:9053-61. doi: 10.1158/0008-5472.CAN-10-2880

119. Beatty GL, Haas AR, Maus MV, Torigian DA, Soulen MC, Plesa G, et al. Mesothelin-specific chimeric antigen receptor mRNA-engineered $\mathrm{T}$ cells induce anti-tumour activity in solid malignancies. Cancer Immunol Res. (2014) 2:112-20. doi: 10.1158/2326-6066.CIR-13-0170

120. Adusumilli PS, Cherkassky L, Villena-Vargas J, Colovos C, Servais E, Plotkin $\mathrm{J}$, et al. Regional delivery of mesothelin-targeted CAR $\mathrm{T}$ cell therapy generates potent and long-lasting CD4-dependent tumour immunity. Sci Transl Med. (2014) 6:261ra151. doi: 10.1126/scitranslmed.3010162

121. Servais EL, Suzuki K, Colovos C, Rodriguez L, Sima C, Fleisher M, et al. An in vivo platform for tumor biomarker assessment. PLoS ONE. (2011) 6:e26722. doi: 10.1371/journal.pone.0026722

122. Adusumilli PS, Zauderer MG, Rusch VW, O'Cearbhaill RE, Zhu A, Ngai DA, et al. Abstract CT036: A phase I clinical trial of malignant pleural disease treated with regionally delivered autologous mesothelin-targeted CAR T cells: Safety and efficacy. Cancer Res. (2019) 79:CT036. doi: 10.1158/1538-7445.AM2019-CT036

123. Adusumilli PS, Zauderer GM, Rusch VW, O'Cearbhaill RE, Zhu A, Ngai DA, et al. Regional delivery of mesothelintargeted CAR $\mathrm{T}$ cells for pleural cancers: safety and preliminary efficacy in combination with anti-PD-1 agent. JCO. (2019) 37:15(suppl):2511. doi: 10.1200/JCO.2019.37.15_suppl.2511

124. Schuberth PC, Hagedorn C, Jensen SM, Gulati P, van den Broek M, Mischo A, et al. Treatment of malignant pleural mesothelioma by fibroblast activation protein- specific re-directed T cells. J Transl Med. (2013) 11:187. doi: 10.1186/1479-5876-11-187

125. Curioni A, Britschgi C, Hiltbrunner S, Bankel L, Gulati P, Weder W, et al. 1226PA phase I clinical trial of malignant pleural mesothelioma treated with locally delivered autologous anti-FAP-targeted CAR T-cells. Annonc. (2019) 30:v501. doi: 10.1093/annonc/mdz253.052

126. Inamoto $\mathrm{T}$, Yamada $\mathrm{T}$, Ohnuma $\mathrm{K}$, Kina $\mathrm{S}$, Takahashi $\mathrm{N}$, Yamochi $\mathrm{T}$, et al. Humanized anti-CD26 monoclonal antibody as a treatment for malignant mesothelioma tumors. Clin Cancer Res. (2007) 13:4191200. doi: 10.1158/1078-0432.CCR-07-0110

127. Dang NH, Torimoto Y, Schlossman SF, Morimoto C. Human CD4 helper $\mathrm{T}$ cell activation: functional involvement of two distinct collagen receptors, 1F7 and VLA integrin family. J Exp Med. (1990) 172:64952 doi: 10.1084/jem.172.2.649

128. Angevin E, Isambert N, Trillet-Lenoir V, You B, Alexandre J, Zalcman G, et al. First-in- human phase 1 of YS110, a monoclonal antibody directed against CD26 in advanced CD26-expressing cancers. Br J Cancer. (2017) 116:1126-34. doi: 10.1038/bjc.2017.62

129. Nakano T, Kuribayashi K, Mikami K. Possible new therapeutic agents for malignant pleural mesothelioma: anti-CD26 monoclonal antibody and naftopidil. Expert Rev Anticancer Ther. (2016) 16:1097-9. doi: 10.1080/14737140.2016.1241150

Conflict of Interest: The authors declare that the research was conducted in the absence of any commercial or financial relationships that could be construed as a potential conflict of interest.

Copyright (c) 2020 Nicolini, Bocchini, Bronte, Delmonte, Guidoboni, Crinò and Mazza. This is an open-access article distributed under the terms of the Creative Commons Attribution License (CC BY). The use, distribution or reproduction in other forums is permitted, provided the original author(s) and the copyright owner(s) are credited and that the original publication in this journal is cited, in accordance with accepted academic practice. No use, distribution or reproduction is permitted which does not comply with these terms. 